\title{
The Concept of Self-Harm in Toni Morrison's Sula
}

\author{
R.M.Prabha \\ Ph.D. Scholar \\ Manonmaniam Sundaranar University \\ Tirunelveli, Tamil Nadu \\ prabharmk@gmail.com
}

\begin{abstract}
Sula is Toni Morrison's second novel published in the year 1973. This novel depicts the story of the life of two black women friends Sula and Nel and about the community in which they lived. The novel can be called a female bildungsroman which runs through the lives of these two women from their childhood to maturity and to death. Sula was nominated for National Book Award in 1975 and received the Ohioana Book Award. In the novel Sula there is an under-current of self-harm that runs throughout the novel. The subject of 'self-injury' is also seen to be propagating through the novel. This gloomy background tone of self-injury gives the reader a melancholic taste of the novel. The concept is unique and is exploited very well in the novel. Likewise, the word 'Death' is repeated again and again in the novel and its presence is intensified by the death of many characters throughout the novel. Undeniably, this further enhances the sullenness that is blatantly evident while reading the novel. This paper focuses on the concept of self-injury that reverberates through Toni Morrison's novel Sula.
\end{abstract}

Keywords: Self-injury, self-mutilation, self-inflict, suicide, death.

\section{INTRODUCTION}

According to the Mayo clinic, non-suicidal self-injury, simply called self-injury is the act of deliberately harming the surface of one's own body. The term 'self-harm' is generally understood to mean deliberately inflicting injury on oneself [1]. The concept of self-harm resonates through the works of Toni Morrison. Interestingly, Toni Morrison's thesis for her M.A. degree was on suicide namely 'Suicide and Alienation in the Works of Virginia Wolf and William Faulkner.' Notably, there are a lot of self-inflicted deaths and self-destruction in her novels. In Beloved, a woman jumps overboard during the middle passage. Robert Smith in Song of Solomon jumps from the top of Mercy Hospital. Rose Dear, mother of Violet in Jazz drowns herself in a well.

Sula is a multi-faceted novel. Sula is set in Medallion, Ohio. This small town with its close relationships among the neighbors essentially has two segments. One is the valley where the whites live and the other is Bottom where the blacks live. The novel is all about the growth, evolution, progress, and annihilation of a person, a friendship, and a community. The novel also explores the ties between two black girls and community.

\section{SELF-INJURY}

Self-mutilation and self-inflicted injury are seen to recur many times and the notion resonates very well in the novel Sula. In the beginning of the novel, Eva Peace, a strong black woman indulges in self-mutilation. Eva Peace, Sula's grandmother, deliberately loses her leg in order to achieve monthly insurance to earn a living for her family. Eva was leading a miserable life while her husband, Boy Boy engaged himself in womanizing, drinking and abusing her. He abandons Eva and her three children after five years of his marriage. When he leaves, "Eva had only $\$ 1.65$ and 5 eggs, three beets and no idea of what or how to feel. The children needed her; she needed money, and needed to get on with her life. But the demands of feeding her three children were so acute she had to postpone her anger..." (Sula 32).She remained orphaned and was directionless to go anywhere. At that in exorable situation, Eva controls her emotions, postpones her anger and molds her confidence. Initially, she seeks help from her neighbors. She senses that her neighbors could not afford to feed her children for too long. Hence, she decides to find a way to earn enough money to give her children some basic needs. Eva one day left all of her children with the Suggs, saying that "she would be back the next 


\section{R.M.Prabha}

day. Eighteen months later she swept down from a wagon with two crutches, a new black pocketbook, and one leg" (Sula 37). The author does not exactly reveal how Eva lost her one leg. However there is evidence in the novel that Eva received monetary benefit after losing her leg. And Eva returns only after eighteen months from departure. The eighteen months may have been the recovery time that she probably needed to heal the wounds of her amputated leg.

The proof for Eva to have nurtured the self-injuring instinct within herself can be drawn from the incident when her daughter Hannah catches fire. Eva is found to jump out of the window from the second floor to save her daughter Hannah, who is engulfed in fire. Eva does not care for herself before taking such a decision to jump from the second floor. Eva was casually looking through the window, "... and it was then she saw Hannah burning... She lifted her heavy frame up on her good leg, and with fists and arms smashed the windowpane. Using her stump as a support on the window sill, her good leg as a lever, she threw herself out of the window. Cut and bleeding she clawed the air trying to aim her body toward the flaming, dancing figure. She missed and came crashing down some twelve feet from Hannah's smoke" (Sula 76). She fails to save her daughter. She also gets deeply wounded and had to be admitted in a hospital for treatment. Hence, Eva in this novel deliberately harms herself twice. Though, the second time, the act of self-harm is triggered primarily by 'motherly love' to protect Hannah, it is a loss of self-respect and self-care that made her to take up such a fatal adventure.

Eva in Sula is depicted as a strong woman. The matriarchal Eva runs the household from a rocking chair fitted into a child's wagon. Her dominating attitude is reflected time and again in the novel. She has a strong and determined mind. More importantly she believes firmly in all her decisions. She has no second thoughts about her decisions and choices. For instance, her son, Plum, returns from World War I terribly worn-out and sinks under his gloom into drunkenness and drug addiction. Eva's consecration to Plum does not allow her to watch him deteriorate. Thus, after rocking him to sleep one night, Eva kills him by soaking his bed with kerosene and lighting it. This act of Eva can also be perceived as a self-inflicting behavior as she dares to destruct her family for a specific reason. Destruction of one's own family by causing physical harm to blood relations may also be perceived as a self-inflicting behavior. This kind of behavior is analogous to the infanticide in Beloved by Toni Morrison. Se the in Beloved kills her two year old daughter to prevent her from being abused in slavery.

The main character of the novel, Sula, also indulges in self-injury when she was a school going girl. Once, Sula and her friend Nel happen to face a band of teenage Irish boys daily on their way to school. With the intention of getting rid of them Sula, instead of threatening the boys, cuts off the tip of her finger. Sula threatens the boys, pulling out her grandmother's "paring knife... Holding the knife in her right hand, she... presses her left forefinger down hard on its edge... She slashed off... the tip of her finger" and taunts, "if I can do that to myself, what you suppose I'll do to you?" (Sula54). Consequently, the boys are horrified and they run away. The critic Willis crisply remarks, "Sula's self-mutilation symbolizes castration and directly contests the white male sexual domination of black women that the taunting and threatening boys evoke" [2]. Sula's act is in agreement with what Richardson says, "Many young people do it in order to release feelings of anger and self-hatred - to alter their state of mind. It can be a way to communicate distressing feelings that are difficult for them to express" [1]. Sula's acts and finally her life can also be thought of as a process that makes others around her to define them. Her act warns the boys to mind their business. Raja Rao pertinently sums up the life of Sula, "Sula never competed: she simply helped others define themselves" [3]. Sula's preparedness to mutilate her is a way of showing strength. The boys were taller, older, and stronger, and she may not succeed by just attacking them. Hence, she chooses to harm herself. She has the most control over herself. Offending herself shows Sula's inner courage. The boys hastily leave, realizing that their petty bullying is no match for Sula's actual self-violence and boldness.

Sula was just thirteen years of age when the incident with the Irish boys occurred. According to Chapman and Kim, "most people who harm themselves begin this behavior at the age of thirteen or fourteen... self-harm is most common among adolescents and young adults" [4]. Sula was an adolescent and Eva was young when they indulged in their first self-harm. According to Chapman, self-harm is rarely seen after fifty and less after forty years of age. The second self-harm that Eva had in her life may be an exception to this. It is important to note that both Eva and Sula did not have any stress disorder to continually inflict injury on them. Both were psychologically strong to cope with 
any adverse environment. There is no incident in the novel that could portray these two women as weaklings. Instead, they are depicted as strong and wild.

Sula represents the radical and revolutionary aspects of black women within the community. She attempts to create a new standard of self-identity for herself. She rejects her upbringing under the hand of her mother and objects to her grandmother's notions about marriage. When asked by her grandmother Eva, she replies, "I don't want to make somebody else. I want to make myself" (Sula 92). Rao precisely observes, "She [Sula] is liberated and hardly bothered with moral precision and circumspection. She has sexual union with unlimited people. She knows no alienation for she is imbued with more than her share of funkiness" [3]. Sula gets her unique legacy of attitude from her grandmother Eva and mother Hannah. Sula aptly conforms to the notion of the famous proverb, "Like mother; like daughter." Daughters often bear a strong resemblance to their mothers. And daughters are inclined to do what their mothers did before them. The personality and behaviors of Sula were found to be similar to those of Hannah. Her sexual life was akin to her mother Hannah's life. Her rigid attitude with a tint of self-inflicting instinct is akin to the uniqueness Eva possessed.

Toni Morrison crafts Sula to represent the inverted figures of conventional black women. She is unconventional and unsettled. Sula was bold and strong like Eva. She inherited the maternal characters from both Eva and Hannah. The prompt and unhesitating act of cutting her fingertip is analogous to the losing of one leg by Eva. Rhodes aptly observes, "Sula dared to live her life outside the safe boundaries of her community, but she lived life on her own terms. Not many AfricanAmerican women in the community had Sula's nerve or guts"[5].

According to the psychologist Walsh "'Self-injury' is intentional, self-effected, low-lethality bodily harm, of a socially unaccepted nature, performed to reduce and/or communicate psychological distress" [6]. Eva's intentional self-effected harm is non-lethal and is performed to reduce distress and get a way out in her miserable life. Similarly, Sula's act is non-lethal and is performed to communicate the distress. There are many ways in which self-harm can be grouped or classified. According to Veague and Collins self-harm can be divided into four major types; Major, Stereotypic, Compulsive and Impulsive type [7]. Psychologist Walsh classifies self-harm into two major types; direct and indirect. Direct self-harm produces immediate damage to self and the intention is mostly unambiguous. Both Sula and Eva did direct self-harm to themselves. In indirect self-harm, the damage is cumulative and not immediate. The intention is often ambiguous. Indirect self-harmers often deny their intent to self-harm. According to Walsh, the "common examples of indirect self-harm are patterns of substance abuse...that damage physical health" [6]. There are a few characters in the novel Sula who deliberately engage in indirect self-harm. Plum, Eva's son is seen in the novel as a heroin addict. He was drug-dependant, dejected and had lost his senses due to drug overdose. Eva's husband Boy Boy is also portrayed as a drunkard. Similarly, the character Shad rack and Tar Baby in Eva's house were heavy alcoholics. Morrison says, Tar Baby, “...was a mountain boy who stayed to himself, bothering no one, intent solely on drinking himself to death... For it soon became clear that he simply wanted a place to die privately but not quite alone" (Sula43).

In The Bluest Eye by Toni Morrison there is another type of self-inflicting behavior that is seen. In The Bluest Eye, the character Pauline is shown to greatly neglect her household because of her racial self-loathing instinct. Pauline readily abandons her children and spouse for no reason other than racial self-hatred. Though there is no physical harm inflicted, this sort of negligence on one's own self and family can be eventually destructive to all the people in the household. Pauline by neglecting her family does a kind of psychological self-harm to herself and her family.

\section{SUICIDE DAY}

Suicide is the most extreme form of self-harm. David Emile Durkheim $(1858$-1917) was a French sociologist, social psychologist and philosopher. Durkheim had defined suicide and classified it into four major types. According to him, “...the term suicide is applied to all cases of death resulting directly or indirectly from a positive or negative act of the victim himself, which he knows will produce this result" [8].

In the initial part of the novel, the character Shadrack comes home from the World War I after being injured in the face and head. Shadrack suffers a psychic injury from the war. During World War I, Shadrack, who was barely twenty and his comrades, met the enemy on a French field in December 1917. He happens to witnesses the brutal death of his friend whose body continues moving forward 


\section{R.M.Prabha}

even after his head is severed and cut off from his body. This encounter with death and Shadrack's experiences in war leave him with Post Traumatic Stress Disorder. He is admitted and treated in the Veterans Hospital. Unfortunately, he could not be completely mended and continues to have hallucinations and outbursts. Though he had survived death in World War I, he was shell-shocked and was in a state of shattered mind. He suddenly attacks a male nurse in the Veterans Hospital when the nurse attempts to feed him. Though he was not fully healed and restored, the Veterans hospital decides to release and discharge Shadrack in order to make room for other sick patients.

Shadrack was put into confinement after the attack. However, his illness gets compounded and disturbed mind becomes more agitated in the jail though he is unable to appropriately perceive it. In jail, he notices the reflection of his face in the toilet water. He finally perceives his facial injury in the water. After he sees a truer picture of himself, he becomes a bit calm and is able perceive a broader conception of his identity. His self-concept included the possibility of suicide. After his release from jail, he creates National Suicide Day, which almost no one in the town took seriously. He declares all by himself that January 3 would be National Suicide Day to order and focus experience. But it was as if his self-concept was so low that he felt like one of the walking dead. Suicide is a very selfish thing to do, depriving others through the loss, and depriving the self of life itself. Shadrack knew very well the whiff of death and was petrified of it, for he could not anticipate it. But if he knew when death could become imminent and come true, then probably there was nothing to fear for. According to Shadrack"If one day a year were devoted to it [death], everybody could get it out of the way and the rest of the year would be safe and free" (Sula 19). Shadrack continues his parade on the same day every year. Initially, people from Bottom gave little importance to Shadrack and his suicide day. However, over years they got used to him and to the day to an extent that it became the fabric of life up in the Bottom. It was Tar baby who first willingly accepted the idea of the 'National Suicide Day.' Morrison says,

The people either accepted his own evaluation of his [Tar Baby] life, or were indifferent to it. There was, however, a measure of contempt in their indifference, for they had little patience with people who took themselves that seriously. Seriously enough to try to die. And it was natural that he, after all, became the first one to join Shadrack--Tar Baby and the deweys--on National Suicide Day. (Sula 43)

Towards the end of the chapter, the 'National Suicide Day' gains importance again. Sula was already dead and people in Bottom were happy about her death. On the eve of National Suicide Day in 1941, Shadrack is bounded by solitude. He looks around for Sula's purple-and-white belt, the only proof of his only visitor ever in his house. Many years ago, a weepy, startled girl with a tadpole-like birthmark over one eye had come to his house. She had looked so nervous that he tried to comfort her with some words of reassurance, but he could manage only one word: "Always." Then Sula had run away, leaving her belt behind. For the first time since the inception of National Suicide Day, Shadrack wanted to stay home with the memory of his one visitor. Morrison says, "Perhaps that was why for the first time after that cold day in France he was beginning to miss the presence of other people" (Sula144).

Shadrack also remembers that Sula is no more. The sense of loneliness gets deeper and deeper in his mind. It was the second day of the New Year 1941, when Shadrack was contemplating his loneliness and the absence of Sula. And for the first time he was hesitant to do his routine parade for the suicide day. Morrrison says, "By his day-slashed calendar he knew that tomorrow was the day. And for the first time he did not want to go" (Sula 147). He thinks that celebrating the 'suicide day' was not doing any good. Sula was another person whom he knew very well and remembered most of his days in his room by the memento that hung on the nail on his wall. In-spite of all the suicide days sula's face was the second one he knew very well who was no more. Morrison describes his feeling,

In the hallway he passed an open door leading to a small room. She lay on a table there. It was surely the same one. The same little-girl face, same tadpole over the eye. So he had been wrong. Terribly wrong. No "always" at all. Another dying away of someone whose face he knew. It was then he began to suspect that all those years of rope hauling and bell ringing were never going to do any good. He might as well sit forever on his riverbank and stare out of the window at the moon. (Sula147)

\section{DEATH}

To Shadrack's surprise, in the year 1941, National Suicide Day is celebrated by a lot of the townspeople. He was somehow sure that this suicide day would be the last of all. In the afternoon, 
drenched in sunlight and "certain that this would be the last time he would invite them to end their lives neatly and sweetly, he walked over the rickety bridge and on into the Bottom" (Sula 148). Many people turned out to follow him, strutting, skipping, marching, and shuffling their way through the town. They marched up to the tunnel on the New River Road. In a state of mob anger and frustration because the tunnel construction jobs have been given to whites rather than to blacks for so many years, the townspeople climbed over the fence and smashed the construction site. The engrossment of the notion of suicide by the people of bottom may fit into the category 'Fatalistic Suicide' as described by Durkheim. The townspeople were excessively regulated and their futures were pitilessly blocked and passions violently choked by the oppressive discipline. According to Durkheim, in overly oppressive societies, people may prefer to die than to carry on living within their society [8].However it was just the idea that was accepted by the people and no one would have wanted to kill themselves in actual fact. Their furious pitch of joy and revenge outraged which was fed by years of oppression, lost wages, and the poverty they have come to accept as a way of life. Unexpectedly, the tunnel collapses in a wall of water, ice, and mud. As a result, many of the townspeople get killed, while Shadrack stands high up on the riverbank, ringing his bell. The tunnel, which initially symbolized freedom from the clutches of poverty and prejudice, deceived the townspeople. Paradoxically, Shadrack reluctantly leads those who rejoiced over Sula's death to the exemplary celebration of National Suicide Day. He stands high on the riverbank, like a prophet ringing his bell on Judgment Day, as he watches a petrified flock of his community in a scene of sacrifice and judgment. Finally, the suicide day of 1941 brings the death of numerous people of Bottom. Death resounds again and again in the novel literally. In the beginning, the readers witness the death of the little boy, namely Chicken Little. And the middle chapters witness the death of Eva's children Plum and Hannah. Both succumb to fire while Chicken Little's life is taken away by water. Towards the end of the novel the main character of the novel, Sula, dies in her own style. Death is talked about much in the novel as much as it is witnessed by the readers.

The presence of the 'National Suicide day' in the novel is unusual and unique. Toni Morrison devoted two chapters for the description and main events of the 'suicide day'. The reason Toni Morrison gave such an importance to 'suicide' may reflect the impact on her from her research on 'suicide' during her master's degree program. The 'suicide day' though was found to be of little importance in the beginning of the novel, finally gets great emphasis from Morrison. 'Suicide day' ultimately involves the actual death of many people in the novel.

\section{Conclusion}

The presence of self-harm in the novel is augmented by its repetition and inclusion of the unique 'Suicide day.' Both Sula and her grandmother Eva practiced self-harm. Their attitude is similar. Sula had the same quality in her as her grandmother. Toni Morrison has added to the sullenness of the novel by giving extra importance to the 'suicide day.' The event that happens in the last 'suicide day' in the year is a direct result of the frank internalization of the idea of 'suicide' by the community. Many people die on the last 'suicide day' which is weird and disastrous. Hence, Toni Morrison phenomenally introduces the concept of 'Self-Harm' and maintains it throughout the novel and successfully emphasizes it eventually in the end. Toni Morrison makes the presence of this unique concept of self-harm vivid till the end of the novel. The death of townspeople, though was caused by a catastrophic event and may not be directly related to self-harm, it is triggered and started by the people themselves as they willingly accepted the notion of celebrating such a notorious 'suicide day.' Besides this, the word 'Death' is seen to resound over and over again literally and through multiple incidents involving the actual death of many characters in the novel producing a melancholic mood to the novel. Hence, the concept of self-harm can be said to be present uniquely and abundantly in the novel Sula.

\section{REFERENCES}

\section{Primary source:}

Morrison Toni, Sula. London: Vintage Books, 1973. Print.

\section{Secondary sources:}

[1] Richardson, Celia. Self-harm: Understanding the Causes and Treatment Options. Update NT. 13 April 2004. Vol. 100 No. 15. Print. 
[2] Gates Jr., H. L. and Appiah K.A. Toni Morrison Critical Perspectives: Past and Present. New York: Amistad Press.1993. Print.

[3] Rao E. R. African-American Women Writers and the Aesthetics of Marginality with Special Reference to Toni Morrison. IJAS.1993. Print.

[4] Chapman L. Alexander, Gratz L. Kim. Freedom from Self-Harm: Overcoming Self-Injury with Skills from DBT and Other Treatments. New Harbinger Publications, 01-May-2009. P 18. Print.

[5] Rhodes Lisa R. (2001). Toni Morrison: Great American Writer. USA: Franklin Watts. Print.

[6] Walsh W.Barent. Treating Self-injury: A Practical Guide. Guilford Press, 2012. P 4. Print.

[7] Veague B. Heather, Collins E. Christene. Cutting and Self-Harm. Info base Publishing. 01-Jan2009. P 5. Print.

[8] Durkheim Emile. Suicide: A Study in Sociology. New York, The Free Press, 1951. Print.

\section{AUTHOR's BIOGRAPHY}

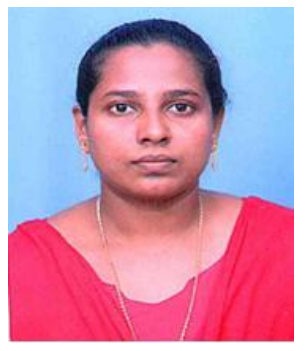

R.M. Prabha is a research scholar, currently pursuing her Ph.D. course at the Manonmaniam Sundaranar University in Tirunelveli. Her main area of interest is Afro-American literature. She has extensively done research on the author Toni Morrison and her novels. She completed her under graduate [B.A English] degree course at the Govindammal Aditanar College for Women in Tiruchendur in 2006. She did her Master's degree in English [M.A] and subsequently M.Phil degree in Sarah Tucker College for Women in Tirunelveli. After her graduation she has served the college in which she did her undergraduate degree, as a faculty, Assistant Professor in English for nearly four years. Her project for her M.Phil degree was on the novel Jazz by Toni Morrison. Her current research work also involves Toni Morrison's select novels. 